\title{
Fortifications in Ice-cream with Enhanced Functional Properties: A Review
}

\section{Dolanchapa Sikdar ${ }^{1} \mid$ Rosalin Nath $^{1} \mid$ Kakali Bandyopadhyay ${ }^{1} \mid$ Ishon Mollick $^{1}$}

${ }^{1}$ Department of Food Technology, Guru Nanak Institute of Technology, Kolkata, India

To Cite this Article

Dolanchapa Sikdar, Rosalin Nath, Kakali Bandyopadhyay and Ishon Mollick, "Fortifications in Ice-cream with Enhanced Functional Properties: A Review", International Journal for Modern Trends in Science and Technology, Vol. 06, Issue 05, May 2020, pp.: 131-138; https://doi.org/10.46501/IJMTST060523

\section{Article Info}

Received on 02-April-2020, Revised on 28-April-2020, Accepted on 05-May-2020, Published on 17-May-2020.

\section{ABSTRACT}

Enrichment of food by the addition of essential micro-nutrients like trace elements and vitamins to food is known as fortification. It can be carried out under initiatives such as Public Health Policy which aims in reducing the number of people with dietary deficiencies within a group of people or population. Ice-creams are well known dessert, and very much in demand among the children. So it is very important to keep its sensory factors in mind and make nutritive additions in it. To meet the demands of the consumers various natural ingredients are used to fortify ice-creams. Works have been done on combining ice-cream with biologically active molecules and produce functionally potential products. There are reports of making natural anti-oxidant ice-cream, experimenting it with cocoa powder, hazelnut, green-tea and ginger extract. Ice-cream fortification with fish-protein powder has turned to be effective in enhancing food value, but studies on its stability during storage and consumer acceptance are highly recommended. Researchers worked on incorporating dietary fibers in ice-cream like wheat, oats, bamboo, apple and orange. Its influence was checked on the basis of rheological, textural, sensory properties and probiotic culture survival of the ice-cream, to enhance the structural characteristics and cultural viability. Addition of Inulin in ice-creams as fat-replacers increased the viscosity and also made it resistant to melting. Hydrocolloids bind water and oil and adding them in ice-creams enhanced the micro-viscosity. Ice-creams were fortified with vitamins and minerals with successful attempts for example Vitamin D3, calcium and zinc fortifications. This study aims to review the various fortifications of ice-cream till date, using different nutritional components, hence fulfilling the nutritional needs of human-beings.

KEYWORDS: Fortification, Vitamins, Dietary deficiency, Biologically active molecules, Sensory properties, Micro-viscosity, Dietary fibers.

Copyright (C) 2014-2020 International Journal for Modern Trends in Science and Technology

DOI: https://doi.org/10.46501/IJMTST060523

\section{INTRODUCTION}

When any food product is developed, the first few things that must be kept in mind is fulfilling the consumers' expectancy and checking their acceptance of the product. It is a game of combining sensory properties of food with nutritional factors. Any kind of deficiency in the daily dietary routine causes the development of technologically advanced food (enriched in essential micronutrients). Fortification may be defined as the enrichment of food by the addition of essential nutritive. The fortification of foods is often 
regarded as the most cost-effective long-term approach (Richard F. Hurrell, 1997). Initiatives like the Public Health Policy goals at the attainment of highest possible health level and being fit and fine for all human beings, as long as they live. In such a scenario, it is extremely important to target children and make neutraceutically advanced food available for them as nutritive is required in their body during growth. Hence enrichment of the type of food that attracts children is very important. Though ice-cream does not fall in the part of our staple diet, but still it is a good idea to add nutritive in ice-cream as it attracts children as well as people of various ages very easily. The ice-cream is popular because of its several features, like partial freezing and refreshing sensation produced when the product is eaten, its taste and aroma (Daniel Granato et al., 2018).

Moreover researches have proved that fortifications in ice-creams generally increase its emulsion stability (H.D.Goff et al., 1989) and have a higher success rate over other fortified products. Thus it is a smart way as children would get most of the goodness from these fortified ice-creams. Combining bio-active molecules with ice-creams is an interesting way to develop a popular dessert with a tag of healthy and nutritious food. Current progress in ice-cream is highlighting significant improvement of the textural, rheological and sensory properties of the end product.

\section{FORTIFICATION OF ICE-CREAM}

According to the American Council on Science and Health, "Functional foods is considered to be those complete, fortified or enhanced foods providing health benefits beyond the provision of essential nutrients (vitamins and minerals), when they are consumed at efficacious levels as part of a varied diet on a regular basis." (Hasler CM, 2002). Including bioactive compounds can be done by direct addition in free form, using herbal extracts, rich in active compound (spices, hazelnut, green tea and even ginger). Addition of carriers are also done where the active compound is physically or chemically entrapped. Ice-cream can be manufactured as conventional, protein enriched, fiber enriched, vitamin and mineral fortified, fat-free, low-sucrose products, keeping the sensory factors same. Fortification is an ever evolving process and keeps on increasing with day. But there are a number of problems for such nutritive modifications. A number of factors might resist the modification in the ice-cream. With increasing storage or in any step of manufacture the nutrition incorporated might be lost.

\subsection{Anti-oxidants in ice-creams}

One of the main functions of our body is to digest the food we eat which causes break down of food generating free radicals (potentially harmful for our body). They cause oxidation in our body causing several diseases related to heart and lungs or even cancer. Anti-oxidants protect our body from free radicals by donating negative charge (electrons) to free radicals and making them stable (I S Young and $J$ V Woodside, 2001). Sanguigni worked on the effects of a natural antioxidant ice-cream (Sanguigni V et al., 2017). It was based on a mixture of dark cocoa powder, hazelnut and green tea extract (rich in polyphenol).

High polyphenol content in food improves the vascular function and physical performance, through an oxidative stress-mediated mechanism but still there is an ambiguity related to this (Sanguigni V et al., 2017). Anti-oxidant fortified ice cream is potentially effective in counteracting oxidative stress in all individuals as well as in patients suffering from many chronic and degenerative diseases. It has also proved to be durable and stable over time (Daniel Granato et al., 2018). Ginger (Zingiber officinale) is rich in antioxidants. It also contains pungent components like gingerols and shogaols. Ginger has been highlighted as a potential functional food for use in new product development. Gabbi, Bajwa and Goraya compared the properties of ice cream by introducing ginger in different ways (Gabbi DK et al., 2017)

Ginger juice and paste from 2 to $8 \% w / w$, ginger candy from 5 to $20 \% \mathrm{w} / \mathrm{w}$, and ginger powder from 0.5 to $2 \% w / w$. Inclusion of the juice and paste reduced significantly total solids, fat and protein, whereas ginger powder and candy increased solids and crude fiber. The antioxidant activity and total phenols increased in all formulations. Samples with $6 \%$ juice and $4 \%$ paste were good in terms of flavor and accepted the most. Ice cream containing more than $10 \%$ candy and $1 \%$ powder was not accepted due to its flavor and pungency.

\subsection{Fish proteins in ice-cream:}

Fish is an important food with the evidence of potential health benefits which relate to the utilization of proteins of high biological value, omega-3 polyunsaturated fatty acids (PUFAs) as well as micronutrients (Gholam Reza Shaviklo et al., 2011). Fish can also be beneficial for women during pregnancy for development of the child (Daniels JL et al., 2004; Gidding SS et al., 2005; 
Sidhu KS, 2003). The effect of fortification with different levels of fish protein powder (FP) of Persian ice cream was investigated on the basis of the sensory and chemical properties. Zero, 30 and $50 \mathrm{~g} \mathrm{~kg}$ of $1 \mathrm{FP}$ in ice-creams was investigated during storage at $-18{ }^{\circ} \mathrm{C}$ for 4 months. Ice creams fortified with 50 and $30 \mathrm{~g} \mathrm{~kg}-1 \mathrm{FP}$ had significantly higher protein and lower fat content than ice-cream with zero\% FP. Even tests were conducted with 83,69 and $51 \mathrm{~g} \mathrm{~kg}$ of $1 \mathrm{FP}$ in ice-creams and it showed results as 215, 204 and $181 \mathrm{~g} \mathrm{~kg}-1$ solid non-fat, respectively. The levels of fat, lactose, acidity and $\mathrm{pH}$ were same in all the products. When sensory properties were concerned it was a bit different for the fortified samples, which included fading of color, decrement of cohesiveness, and increment of sandy texture due to insoluble lactose crystals (El-Neshawy AA et al., 1988; Livney YD et al., 1995), thus decrement of sweet taste but increment of fish flavor. When fortified samples kept at $-18^{\circ} \mathrm{C}$ were investigated after 2 months storage, a very off-odour came from the ice-cream and also the ice-cream turned rancid (lipid oxidation of fish protein) (Li $Z$ et al., 1997) and hydrolic rancidity of milk fat (Focant $\mathrm{M}$ et al., 1998) and then it tasted bitter. In the optimization study of ice cream with 10,20 or $30 \mathrm{~g} \mathrm{~kg}$ of 1 fish protein powder no differences were observed with respect to color, odour, flavor, texture and overall acceptability. When fortified and control samples were checked, no differences were found just after production except for color. Fortified ice creams scored lower for color than the control product. Also significant differences were detected between products during storage.

\subsection{Nutritive fortifications like dietary fibers}

Ice-creams have also being fortified with dietary fibers like, wheat, oats, bamboo, apple and orange in order to enhance the structural characteristics and cultural viability of the ice-cream. The incorporation of dietary fiber into the ice cream mix increased its total solids content. The presence of different dietary fibers and the storage time affected the lactic acid contents of ice- cream samples. The acidity results, determined by titration, showed that fortification with orange, apple, and bamboo fibers increased the acidity of the samples compared with the control and other samples. The percentage of lactic acid content of probiotic ice cream samples changed in the order of orange $>$ apple $>$ bamboo $>$ wheat $>$ control $>$ oat during storage (A. S. Akalın et al., 2018). The addition of citrus fiber and phenolic substances increased the acidity due to the acidic nature of phenolic substances. A fluctuation in acidity value was observed throughout the storage in control and experimental ice creams. No significant differences in color parameters were detected in probiotic ice creams except for the samples fortified with orange and apple fibers (Dervisoglu, M., and F. Yaz1c1., 2006). The addition of orange and apple fibers decreased the lightness value and also enhanced the red and yellow colors of the ice cream (Figuerola F. et al., 2005). They also seemed to be highly consistent. Apparent viscosity, which is proportional to the consistency index, was also higher in these samples. Also addition of apple fiber led to a slight increase in freezing point but addition of wheat fiber resulted in a decrease in freezing point temperature. These changes were attributed to the serum composition enriched in high-molecular-weight biopolymers or high-molecular-weight polysaccharides. But apple fiber fortification led to a significant decrease in ice content and percentage of frozen water. The highest values of hardness were determined in samples supplemented with orange fiber between $\mathrm{d}$ 60 and 180. It was found that an ice cream sample fortified with $1.5 \%$ orange fiber had a low flavor because of increased acidity. Throughout the storage of the samples, only apple fiber ice cream showed a sharp decrease in taste-flavor score at the end of storage. But the texture in these ice-creams remained unchanged and melting rate decreased (Crizel et al., 2014). Textural and sensory features of lemon ice cream have been enhanced with orange fiber (tainara de moraes crizeli et al., 2014), and the effect of rice flour in vanilla ice cream has been investigated. The effect of inulin has been investigated in pro-biotic ice-cream. Inulin increased total counts of lactic acid bacteria (lactobacillus casei and lactobacillus rhamnosus) in probiotic ice-cream (t.dicriscio et al., 2010). A similar prebiotic effect on lactobacillus acidophilus and bifidobacterium animalis $\mathrm{bb} 12$ was not found though, when studied (akalın, a. S., and d. Erişir., 2008). Overrun is basically the amount of air incorporated during the manufacture of ice cream. The overrun of the experimental ice cream samples increased with the addition of the dietary fibers, compared with the control except for the sample containing bamboo fiber. Apple, orange, or wheat fiber fortification increased the incorporation of air into ice-cream attributing to their rheological properties. It was reported that dashers of batch freezers could incorporate more air into samples with higher viscosity (bahram parvar and goff, 2013). It was also reported that 
overrun is directly proportional to viscosity (akalın, a. S., and d. Erişir., 2008).

\subsection{The effect of inulin as a fat replacer and hydrocolloids}

Ice cream is a frozen aerated oil in water emulsion containing partially coalesced fat globules, air bubbles, ice crystals and unfrozen viscous serum (high molecular weight polysaccharides, proteins, mineral salts and water) Ice cream contains $10-15 \%$ fat from dairy or non-dairy sources and is an important component in ice cream which affects dryness, shape retention after freezing process, melting resistance and smoothness after hardening. Berger 1990 and Goff 2002 showed that elimination or replacement of milk fat content from ice cream leads to many defects in the final quality of product. But in recent years, consumers demand low-fat formulations of food products as consumption of fat increase the risk of obesity and coronary heart diseases (Akalın, A. S., and D. Erişir., 2008). So nowadays many fat replacers are fortified in ice cream formulations, to mitigate the undesirable properties of the finished product that might arise from fat reduction or removal (Akbari, M. et al., 2019).

The different level of inulin as fat replacer in ice cream was investigated. Inulin was added at 2, 4 and $6 \%$ to replace milk fat. The experimental ice creams were compared to a control with $10 \%$ milk fat on the basis of chemical composition, overrun, water activity, viscosity, melting rate, hardness and colour value. Sensory properties of the ice cream samples were also evaluated during storage. Ice creams prepared with 2 and $4 \%$ fat substitution were acceptable and similar to the control. The aim of the project was to reduce the fat content in ice-cream formulations. $25 \%$ of butyric and vegetable fats could be replaced with $3 \%$ of inulin, with acceptable textural and sensory characteristics of the final product. Inulin fortification increased the ice cream mix viscosity, improved aeration, and produced ice creams with soft and homogeneous textures (Akalın, A. S., and D. Erişir., 2008). Substitution did not cause any change to the colour characteristics. Hedonic sensory analysis showed that optimized fat-reduced inulin ice cream was not any different from commercial vanilla ice cream.
Table 1: Comparative study between antioxidant rich and control ice-cream (Sanguigni $V$ et al., 2017)

\begin{tabular}{|c|c|c|}
\hline Compounds & $\begin{array}{c}\text { Anti oxidant } \\
\text { Ice cream }\end{array}$ & $\begin{array}{c}\text { Control } \\
\text { Ice-cream }\end{array}$ \\
\hline $\begin{array}{c}\text { Total polyphenols } \\
(\mathrm{mg} / \mathrm{L} \mathrm{GAE})\end{array}$ & 1817 & 96 \\
\hline Epicatechin $(\mathrm{mg} / \mathrm{ml})$ & 9.1 & 0.06 \\
\hline Catechin $(\mathrm{mg} / \mathrm{ml})$ & 10.5 & 0.03 \\
\hline
\end{tabular}

\subsection{Stabilizing capability of Hydrocolloids}

Hydrocolloids are essential ingredients in the process of ice cream making. The major function of polysaccharides in ice cream is to stabilize (control of ice re-crystallization i.e. hardening and storage prevention of phase separation), thickening, texturing, heat shock, and melting resistance. It has been found that inulin and basil gum are becoming popular in producing ice creams (Akesowan, A., 2009; Akbari, M. et al., 2019). Melting examinations are utilized to demonstrate the melting traits and shape preservation of ice cream (Muse, M., \& Hartel, R. W., 2004). Meltdown of ice cream depends on the phenomena of mass and heat transfer. Hydrocolloids can affect the ice cream melting quality, because they have the ability to bind water and subsequently enhance the micro viscosity of ice creams (Marshall, Goff, \& Hartel, 2012). It has been revealed that higher hydrocolloids concentration has usually a direct relationship with the decrease in ice cream melting rate (Cropper et al., 2013; Varela, Pintor, \& Fiszman, 2014). Although, there are technological and consumers' acceptability limitation on the hydrocolloids addition in the ice cream mix; in addition, melting resistance is also strongly dependent on sweeteners and milk solids-not-fat (MSNF) fortifiers. Increasing hydrocolloids causes an increment in serum micro viscosity; hence it will take a longer time for serum to diffuse from the interior layers of ice cream to exterior layers. Moreover, hydrocolloids enhance the overrun of ice creams which subsequently decrease the rate of heat transfer and melting (Soukoulis, Chandrinos, \& OTzia, 2008).

\subsection{Minerals and Trace elements fortification}

Ice cream was made using a tabletop ice cream maker (Delonghi, Toronto, Canada) using milk , 35\% whipping cream, powdered sugar , egg yolks, and vanilla extract. First the milk and whipped cream was mixed at $100^{\circ} \mathrm{C}$ on a hot plate. The egg yolk, sugar and vanilla were pre-blended in a beaker and poured into the mix, with constant stirring. The final mix was stirred under heat until thick custard was formed and cooled to $50^{\circ} \mathrm{C}$. At 
this point, the fortified butter oil emulsion was incorporated into the custard mix at $50^{\circ} \mathrm{c}$ to yield a final concentration of $100,000 \mathrm{IU} \mathrm{kg-1}$ of vitamin D3 in the ice cream. The mix was vigorously mixed by continuous stirring for $15 \mathrm{~min}$ followed by homogenization for $5 \mathrm{~min}$ (Omni-Mixer Homogenizer, London Scientific, London and Canada). The same method was used with the crystalline vitamin D-fortified butter oil emulsion. However, the final concentration of vitamin D3 was $50,000 \mathrm{IU} \mathrm{kg}-1$. After fortification, the mix was cooled to $4^{\circ} \mathrm{C}$ and poured into the ice cream maker to produce the ice cream ( $\mathrm{J}$ Tobias et al., 1981). Batcher of ice cream was stored at $-25^{\circ} \mathrm{C}$. Ice cream samples were analyzed for vitamin D3 content after weeks 0-4. Vitamin D3 fortified ice cream is nutritionally acceptable, can be easily consumed and has a remarkable improvement of vitamin stability in the low-fat formulations (Chansathirapanich, W. et al., 2016). Fat soluble vitamins (vitamin $\mathrm{K}, \mathrm{D}, \mathrm{E}$, and $\mathrm{A}$ ) are found in trace amounts in ice cream and are absent in low-fat and nonfat formulations. The compensation of losses occurring due to heat treatment and skimming is made by formulating ice-creams with minerals and vitamins (Marshall et al., 2003). Fortification micronutrients such as magnesium, zinc, manganese, cobalt, nickel, copper, and pro-vitamin A carotenoids have shown success but still more studies should be carried out in order to check its costing and other factors (Noel et al., 2012). Incorporation of raisin, grape juices and cane molasses has been reported as an efficient way to administer iron in regular chocolate ice cream without affecting texture or flavors (Soukoulis and Tzia, 2010). Adding 5\% to $15 \%$ $(\mathrm{w} / \mathrm{w})$ dried Cape gooseberry pulp in conventional ice creams showed to increase the concentration iron, Manganese, Zinc, and Sulphur without affecting or only slightly decreasing the minerals that are found mainly in ice-creams like Phosphorus, Magnesium, Calcium, potassium, and sodium (Erkaya et al., 2012). The addition of $5 \%$ to $20 \%(\mathrm{w} / \mathrm{w})$ vegetable marrow pulp in ice cream showed a significant increase of Zinc, Potassium, and Iron content, though it induced a significant reduction of the concentration of major minerals, that is, Calcium and Phosphorus (Dagdemir, 2011). Researchers (Hwang et al.,2009) evaluated that the impact of addition of wine grape lees solids $(5 \%, 10 \%, 15 \% \mathrm{w} / \mathrm{w})$ resulted in an both cases which resulted in improved viscosity, reduced melting, and sensory quality (Erkaya et al., 2012; Dagdemir, 2011).

\subsection{Agro-waste in ice-creams}

Most of the by-products of the agro food industry are regarded as rich in natural antioxidants (Ayala-Zavala et al., 2011). Though there are many technological obstacles in the process of utilizing organic wastes mainly in order to formulate it in food and develop a product, but works have been done to formulate fruit and vegetable wastes in ice-creams. The supplementation of ice cream with grape wine lees has proved out to be a grand success. It is a common winery waste rich in polyphenols and DF ice-creams with improved rheological characteristics, reduced freezable content and melting rate without influencing fat destabilization and air incorporation, while also incorporating good amounts of polyphenolics such as anthocyanins. Work has been carried out to fortify ice-cream with pomegranate peel, as it has been investigated to have good amounts of antioxidants and PUFAs. Pomegranate seed oil (PSO) addition in ice-cream has enhanced the antioxidant activity. Work on addition of whey protein isolate in ice-creamsproved to improve the foaming and emulsifying capacity (Puangmanee et al., 2008). Okara or soy pulp or tofu dregs are the insoluble part of soya beans which remains after soya beans are filtered in the production of soy milk. It has been considered as an agricultural waste until it was investigated to have rich amounts of protein and vitamin B 6 along with some essential micronutrients and dietary fibers. Okara incorporation in ice-creams has resulted in the production of ice-creams which are promising in accordance to its sensory factors (Tsutsui, S. ,2008).

\subsection{Probiotic enriched ice creams}

In frozen state ice cream is a colloid consisting of ice crystals, air globules and fat droplets dispersed in a continuous freezing aqueous phase. It also contains polysaccharides, cane and milk sugars, proteins, and minerals (mostly calcium, but also traces of sodium and potassium). The term probiotic is defined as live microorganisms which when orally administered in adequate amounts (106 to $107 \mathrm{CFU} / \mathrm{g})$ confer health benefits to the host (Food and Agriculture Organization of United Nations; World Health Organization- FAO/WHO, 2001). Probiotics can be incorporated into ice cream in free or microencapsulated states. In free state, probiotics can be supplied by either blending an acidified milk base (such as probiotic yogurt, acidified milk, or cream) with the ice cream mix base at the start of production, or by direct administration of the ice cream mix with a single or 
a symbiotic culture starter prior to the whipping-freezing step (Tamime and Robinson, 2007; Soukoulis and Tzia, 2008). Microencapsulated probiotic bacteria are a biopolymer cross-linked or spray/freeze-dried matrices. Employing microencapsulated probiotics for the production of functional ice cream has been a success during the last few years due to the versatile method, the prolonged shelf life of both microcapsules and ice cream, and the minimized impact of the carrier material on the sensory, texture, and structural aspects of the finished product (Mohammadi et al., 2011). Studies are recommended on the freezing processes and post freezing (hardening and frozen storage) conditions, and parameters like ice cream composition (sugars, polysaccharides, protein type, and content), $\mathrm{pH}$, and the presence of oxygen, in probiotic enriched ice-cream as these factors have reported to significantly impact the viability of probiotic bacteria throughout processing. Thus the combination of the probiotic living cells in ice cream is carried out under strict control as much as it is considerable for human consumption (Christos Soukoulis et al., 2014).

\subsection{Flaxseed oil to prepare low fat ice-cream formulations}

The milk fat replacement in ice-cream with flaxseed oil could affect the functional characteristics of ice cream, depending on how much milk fat is replaced. More proportions of milk fat replacement with flaxseed oil resulted in a less viscous and less firm ice-cream with very high meltdown rate. This could be explained due to the differences in the melting temperature of fat or oil. Also the extent of fat flocculation occurring during the concomitant churning and freezing of the ice cream mix determined the firmness. The flocculated fat droplets basically stabilize the air penetrated into ice-cream which contributed to the firm structure of ice cream and resisted meltdown. It has been found that if $2 \%(\mathrm{w} / \mathrm{w})$ flaxseed oil is incorporated in a $12 \%(\mathrm{w} / \mathrm{w})$ ice cream then the overall functionality of the ice-cream is not affected. However, sensory tests will be needed to determine consumer acceptance in terms of the flavor and texture (Kelvin K.T. Goh et al., 2006)

Table 2: Different works on Ice-cream Fortifications

\begin{tabular}{|c|c|c|}
\hline Name of Author & Worked on & $\begin{array}{c}\text { Journal } \\
\text { publication }\end{array}$ \\
\hline Sanguigni V. & Natural & Nutrition (2017) \\
\hline
\end{tabular}

\begin{tabular}{|c|c|c|}
\hline & $\begin{array}{l}\text { Antioxidant } \\
\text { rich ice-cream }\end{array}$ & \\
\hline $\begin{array}{l}\text { GabbiD.K., Bajwa } \\
\text { A.U, Goraya R.K. }\end{array}$ & $\begin{array}{c}\text { Ginger } \\
\text { incorporated } \\
\text { ice-cream }\end{array}$ & $\begin{array}{c}\text { Int. Dairy } \\
\text { Technol (2017) }\end{array}$ \\
\hline $\begin{array}{l}\text { Dervisoglu M., F. } \\
\text { Yzici }\end{array}$ & $\begin{array}{l}\text { Citrus fibre } \\
\text { formulated } \\
\text { ice-cream }\end{array}$ & $\begin{array}{c}\text { Int. Food } \\
\text { science Technol } \\
\text { (2006) }\end{array}$ \\
\hline $\begin{array}{l}\text { El Nagar, G. Clows, } \\
\text { C.M. Tudorica, V. } \\
\text { Kuri, C.S. Brennan }\end{array}$ & $\begin{array}{c}\text { Inulin } \\
\text { incorporated } \\
\text { ice-cream } \\
\end{array}$ & $\begin{array}{c}\text { Int. Dairy } \\
\text { Technol (2002) }\end{array}$ \\
\hline $\begin{array}{c}\text { Chansathirapanich } \\
\text { W., Tansawat R., } \\
\text { Ngamchuachit P. }\end{array}$ & $\begin{array}{l}\text { Calcium and } \\
\text { Vitamin D3 } \\
\text { fortified } \\
\text { ice-cream }\end{array}$ & $\begin{array}{l}\text { Thai journal of } \\
\text { pharmaceutical } \\
\text { sciences (2016) }\end{array}$ \\
\hline $\begin{array}{c}\text { Akbari M., } \\
\text { Eskandari M.H., } \\
\text { Niakosari M, } \\
\text { Bedeltavana A. }\end{array}$ & $\begin{array}{c}\text { Inulin } \\
\text { incorporated } \\
\text { ice-cream }\end{array}$ & $\begin{array}{c}\text { Int. Dairy } \\
\text { Journal(2016) }\end{array}$ \\
\hline $\begin{array}{c}\text { Muse M., Hartel } \\
\text { R.W. }\end{array}$ & $\begin{array}{l}\text { Melting rates of } \\
\text { ice-cream due } \\
\text { to various } \\
\text { fortifications }\end{array}$ & $\begin{array}{l}\text { Journal of dairy } \\
\text { sciences (2004) }\end{array}$ \\
\hline Akesowan A. & $\begin{array}{l}\text { Soy protein } \\
\text { isolate in } \\
\text { ice-cream }\end{array}$ & $\begin{array}{c}\text { Thai Journal Of } \\
\text { Agricultural } \\
\text { Sciences(2009) }\end{array}$ \\
\hline $\begin{array}{c}\text { Aklam A.S, D. } \\
\text { Erisir }\end{array}$ & $\begin{array}{c}\text { Inulin and } \\
\text { oligofructose } \\
\text { enrichment }\end{array}$ & $\begin{array}{l}\text { Journal of Food } \\
\text { Sciences }(\mathbf{2 0 0 8 )}\end{array}$ \\
\hline
\end{tabular}

\section{TEChNICAL HURDLES TO FORTIFY ICE-CREAM}

Fortification is a good technique to apply if it holds good. Many a times the fortification is lost due to factors like temperature, heat and packaging material or if proper hygiene is not maintained. Unit operations used in processing of ice-cream does not degrade vitamins which are added in the dry form. Even whipping and aeration of the mix in freezing temperature does not cause much oxidative losses but the greatest processing losses are due to pasteurization of the mix. The shelf life of fortified ice-creams might decrease with a complete change in its sensory properties. It is thus challenging to fortify ice-creams keeping in mind of both the nutritional factors and sensory properties of the ice-cream.

\section{Discussions and Conclusions}

The global ice cream industry is growing, with projections estimating a global CAGR of over $4 \%$ and annual sales climbing to $\$ 80$ to $\$ 89$ in the next 5 to 7 years. Producers are staying competitive and experimenting with formats and ingredients. Format trends are expressed in two ways: ice-creams are served with and as snacks, such as ice cream sandwiches or as softies, served with 
French fries. Trending ice cream ingredients incorporate new flavors and healthier formulations-including sugar less and reduced sugar varieties-and inclusions such as chocolate or waffle. The sensory properties play a vital role as it determines the overall acceptability of the end product. Some enrichment hold good while some come out with big failures, hence are unacceptable by public. If chemical composition, $\mathrm{pH}$ and other factors related to taste, texture and appearance alter; if the ice cream is inconsumable, then the fortification turns out to be useless. Scopes are there to fortify ice-creams with other nutritive to make it a whole-some food. Medicinal values can also be incorporated in ice-creams.

\section{Acknowledgement}

Authors in this paper like to express gratitude to the Department of Food Technology, Guru Nanak Institute of Technology for accessing resources necessary for conduction.

\section{References}

1. Akalın A.S., Erişir D. (2008), Effects of inulin and oligofructose on the rheological characteristics and probiotic culture survival in low-fat probiotic ice cream. Journal of Food Science, 73: M184-M188.

2. Akalın A.S., Kesenkas H., Dinkci N., Unal G., Ozer E., Kınık O.( 2018), Enrichment of probiotic ice cream with different dietary fibers: Structural characteristics and culture viability, Journal of Dairy sciences, 101: 37-46.

3. Akbari M., Eskandari M.H., Davoudi Z. (2019), Application and functions of fat replacers in low-fat ice cream: a review, Trends in Food Science \& Technology, 86: 34- 40.

4. Akesowan A.( 2009), Influence of soy protein isolate on physical and sensory properties of ice cream. Thai Journal of Agricultural Sciences, 42: 1-6.

5. Ayala-Zavalaa J.F., Vega-Vegaa V., Rosas-Domíngueza C., Palafox-Carlosa H., Villa-Rodrigueza J.A., WasimSiddiquib Md., Dávila-Aviñaa J.E., González-Aguilara G.A. (2011), Agro-industrial potential of exotic fruit by-products as a source of food additives, Food Research International, 44: 1866-1874.

6. Bahram P.M., Goff H.D. (2013), Basil seed gum as a novel stabilizer for structure formation and reduction of ice recrystallization in ice cream, Dairy Science $\&$ Technology, 93: 273-285.

7. Chansathirapanich,W., Ngamchuachit, P., Tansawat, R. (2016), Effect of fat content on characteristics of ice cream fortified with calcium and vitamin D3, Thai Journal of Pharmaceutical Sciences, 40: 132-138.

8. Chekria R., Noëla L., Milloura S., Vastela C., Kadara A., Sirotb V., Jean-Charles L., Guérina T. (2012), Calcium, magnesium, sodium and potassium levels in foodstuffs from the second French Total Diet study, Journal of Food Composition and Analysis, 25: 297-107.

9. Criscio T.D. , Fratianni A. , Mignogna R. , Cinquanta L. , Coppola R. , Sorrentino E. , Panfili G. (2010), Production of functional probiotic, prebiotic, and synbiotic ice-cream., Journal of Dairy Science, 93:4555-4564.

10. Crizel T.M., Araujo R.R., Rios A.O., Rech R., Flôres S.H. (2014), Orange fiber as a novel fat replacer in lemon ice cream, Food Science and Technology, 34: 332-340.
11. Cropper S.L., Kocaoglu-Vurma N.A., Tharp B.W., Harper W.J.( 2013), Effects of Locust Bean Gum and Mono and Diglyceride Concentrations on Particle Size and Melting Rates of Ice-Cream, Journal of Food Science,78: C811-C816.

12. DagdemIr E.( 2011), Effect of vegetable marrow (Cucurbita pepo L.) on ice cream quality and nutritive value, Asian Journal of Chemistry, 23: 4684-4688.

13. Daniels J.L., Longnecker M.P., Rowland A.S. Golding J.(2004), Fish intake during pregnancy and early cognitive development of offspring, Epidemiology, 15: 394-402.

14. Dervisoglu M. , Yazic1 F.( 2006), The effect of citrus fibre on the physical, chemical and sensory properties of ice cream, Food Science and Technology International, 12: 159-164.

15. El-Neshawy A.A., Abdel Baky A.A., Rabie A.M. Metwally S.A. (1988), Organoleptic and physical properties of ice cream made from hydrolysed lactose reconstituted milk. Food Chemistry, 27: 83-93.

16. Erkaya T., Dağdemir E., Şengül M. (2012), Influence of Cape gooseberry (Physalis peruviana L.) addition on the chemical and sensory characteristics and mineral concentrations of ice cream, Food Research International, 45: 331-335.

17. Figuerola F., Hurtado M.L., Estevez A.M., Chiffelle I., Asenjo F. (2005), Fibre concentrates from apple pomace and citrus peel as potential fibre sources for food enrichment, Food Chemistry, 91:395-401.

18. Focant M., Mignolet E., Marique M., Clabots F., Breyne T., Dalemans D. (1998), The effect of vitamin $E$ supplementation of cow diets containing rapeseed and linseed on the prevention of milk fat oxidation. Journal of Dairy Sciences, 81: 1095-1101.

19. Food and Agriculture Organization of United Nations; World Health Organization- FAO/WHO, 2001.

20. Gabbi D.K., Bajwa A.U., Goraya R.K. (2017), Physicochemical, melting and sensory properties of ice cream incorporating processed ginger (Zingiber officinale), International journal of Dairy Technology, 71:190-197.

21. Gidding S.S., Dennison B.A., Birch L.L., Daniels S.R., Gilman M.W., Lichtenstein A.H., (2005), Dietary recommendations for children and adolescents, Circulation, 112: 2061-2075.

22. Goff H.D., Kinsella J.E., Jordan W.K. (1989), Influence of Various Milk Protein Isolates on Ice Cream Emulsion Stability, Journal of Dairy Science , 72: 385-397.

23. Granato D., Santos J.S., Salem R.D.S., Mortazavian A.M., Rocha R.S., Cruz A.G. (2018), Effects of herbal extracts on quality traits of yogurts, cheeses, fermented milks, and ice creams: a technological perspective, Current Opinion in Food Science, 19: 1-7.

24. Hasler C.M. (2002), Functional foods: benefits, concerns and challenges - a position paper from the American Council on Science and Health., The Journal of Nutrition, 132: 3772-3781.

25. Kelvin Goh K.T., Ye A., Dale N. (2006), Characterisation of ice cream containing flaxseed oil, 41: 946-953.

26. Li Z., Marshall R., Heymann H., Fernando L. (1997), Effect of milk fat content on flavor perception of vanilla ice cream, Journal of Dairy Sciences, 80: 3133-3141.

27. Livney Y.D., Donhowe D.P., Hartel R.W. (1995), Influence of temperature on crystallization of lactose in ice cream, International Journal of Food Science + Technology, 30: 311-320.

28. Marshall R.T., Goff H.D., Hartel R.W. (2012), Ice-cream (Sixth edition), Springer, 371.

29. Marshall R.T., Goff H.D. (2003), Formulating and manufacturing ice cream and other frozen desserts, Food 
And Agricultural Organization of United Nations, 57: 32-45.

30. Mohammadi R., Mortazavian A.M., Khosrokhavar R., da Cruz A.G. (2011), Probiotic ice cream: viability of probiotic bacteria and sensory properties, Annals of Microbiology, 61: 411-424.

31. Muse M., Hartel R.W. (2004), Ice cream: structural elements that affect melting rate and hardness. Journal of dairy science, 87: 1-10.

32. Puangmanee S., Hayakawa S., Sun Y., Ogawa M. (2008), Application of Whey Protein Isolate Glycated with Rare Sugars to Ice Cream, Food Science and Technology Research, 14: 457.

33. Richard F. Hurrell (1997), Preventing Iron Deficiency Through Food Fortification.,_Nutrition Reviews, 55: 210-222.

34. Sanguigni V., Manco M., Sorge R., Gnessi L., Francomano D. (2017), Natural antioxidant ice cream acutely reduces oxidative stress and improves vascular function and physical performance in healthy individuals, Nutrition, 33: 225-233.

35. Shaviklo G. R., Thorkelsson G., Sveinsdottirc K., Rafipourb F. (2011), Chemical properties and sensory quality of ice cream fortified with fish protein, Journal of the Science of Food and Agriculture, 91:1199-1204.

36. Sidhu K.S. (2003), Health benefits and potential risks related to consumption of fish or fish oil, Regulatory Toxicology and Pharmacology, 38: 336-344.

37. Soukoulis C., Chandrinos I., Tzia C. (2008), Study of the functionality of selected hydrocolloids and their blends with $\mathrm{k}$ - carrageenan on storage quality of vanilla ice cream., LWT Food Science and Technology, 41: 1816-1827.

38. Soukoulis C., Fisk I.D., Bohn T. (2014), Ice Cream as a Vehicle for Incorporating Health-Promoting Ingredients: Conceptualization and Overview of Quality and Storage Stability, Comprehensive Reviews in Food Science and Food Safety, 13: 627-655.

39. Soukoulis C., Lyroni E., Tzia1 C. (2010), Sensory profiling and hedonic judgement of probiotic ice cream as a function of hydrocolloids, yogurt and milk fat content, LWT - Food Science and Technology, 43:1351-1358.

40. Tamime A. Y. (2007), Structure of dairy products, Blackwell Publishing Limited, 307.

41. Tobias J., Muck G.A. (1981), Ice cream and frozen desserts., Journal of Dairy Sciences, 64: 1077-1086.

42. Tsutsui S. (2008), Awareness about 'okara' [tofu refuse] and the preference for ice cream with 'okara' added to it, The Agriculture, Forestry and Fisheries Research Information Technology Center 32: 179-182.

43. Varela P., Pintor A., Fiszman S. (2014), How hydrocolloids affect the temporal oral perception of ice cream, Food Hydrocolloids, 36: 220- 228.

44. Young I. S., Woodside J. V.( 2001), Antioxidants in health and disease, Journal of clinical pathology, 54: 176-186. 